\title{
An expanded immunohistochemical profile of osteoclast-rich undifferentiated carcinoma of the urinary tract
}

\author{
Salvatore F. Priore ${ }^{1} \cdot$ Lauren E. Schwartz ${ }^{1}$ Jonathan I. Epstein ${ }^{2}$
}

Received: 9 August 2017 / Revised: 6 September 2017 / Accepted: 3 December 2017 / Published online: 6 February 2018

(c) United States \& Canadian Academy of Pathology 2018

\begin{abstract}
Osteoclast-rich undifferentiated carcinoma of the urinary tract (ORUCUT) is a rare tumor composed of ovoid to spindleshaped mononuclear cells with intermixed or focally clustered osteoclast-like giant cells. Previous studies have demonstrated that the mononuclear cells are neoplastic cells, while the giant cells are reactive cells of histiocytic lineage. The association between these tumors and classic urothelial carcinomas suggest that the mononuclear cells are derived from urothelial cells; however, no studies have been conducted to assess the immunohistochemical profile of ORUCUT with more specific urothelial markers. This study identified 21 cases of ORUCUT and performed immunohistochemistry for GATA3, uroplakin II, and thrombomodulin along with pancytokeratin (AE1/3) on all cases. Mononuclear cells stained positive in 20 cases (95\%) for GATA3 and 19 cases (90\%) for thrombomodulin. None of the mononuclear cells were positive for uroplakin II and only three cases showed focal positivity for AE1/3. The osteoclast-like giant cells were negative for GATA3, uroplakin II, thrombomodulin, and AE1/3, providing additional support to a reactive origin for these cells. Additionally, 15 cases (71\%) were associated with either in situ or invasive urothelial carcinoma. This study provides an expanded immunohistochemical profile for ORUCUT and more definitively supports a urothelial origin for this tumor.
\end{abstract}

\section{Introduction}

Osteoclast-rich undifferentiated carcinoma of the urinary tract (ORUCUT) is a rare tumor. The histology of ORUCUT is similar in morphology to giant cell tumor of the bone, tendon sheath, and soft tissues and is composed of a population of mononuclear cells with intermixed or focally clustered osteoclast-like giant cells (Fig. 1). Similar histology have been noted in undifferentiated carcinomas from other visceral organs including thyroid, gastrointestinal tract, salivary gland, skin, breast, larynx, lung, and female genital tract [1-9].

The largest immunohistochemical study to date identified six cases of ORUCUT [10] from an earlier work by one of the current authors (JIE). An equal number of tumors arose

Jonathan I. Epstein

jepstein@jhmi.edu

1 Department of Pathology, Perelman School of Medicine, University of Pennsylvania, Philadelphia, PA, USA

2 Departments of Pathology, Oncology, and Urology, The Johns Hopkins Medical Institutions, Baltimore, MD, USA from the renal pelvis and bladder. In four of six cases, the mononuclear cells showed positive staining for epithelial markers. However, staining was inconsistent between tumors and only one case was reactive for pancytokeratins (Cam5.2 and AE1/3) and CK7. In contrast, the osteoclastlike giant cells stained identically to normal osteoclasts with positivity for CD68, LCA (leukocyte common antigen), CD51, CD54, and negative for cytokeratins and epithelial membrane antigen (EMA). Based on this staining pattern, the giant cells were considered reactive in nature. Tumors behaved in an aggressive manner with four of the six patients deceased within 15 months of diagnosis, mostly due to disseminated disease. This behavior is more akin to a high-grade carcinoma and stands in stark contrast to the more indolent behavior of giant cell tumor of the bone and soft tissue [11-13].

The evidence suggests that the mononuclear cells in ORUCUT represent the neoplastic cells and the association of these tumors with in situ or high-grade papillary urothelial carcinoma in all six cases supported an epithelial origin. In addition, giant cell tumors in other visceral organs, such as the pancreas, have demonstrated robust epithelial staining in the mononuclear cells [14]. To further assess the histopathogenesis of ORUCUT, this study 

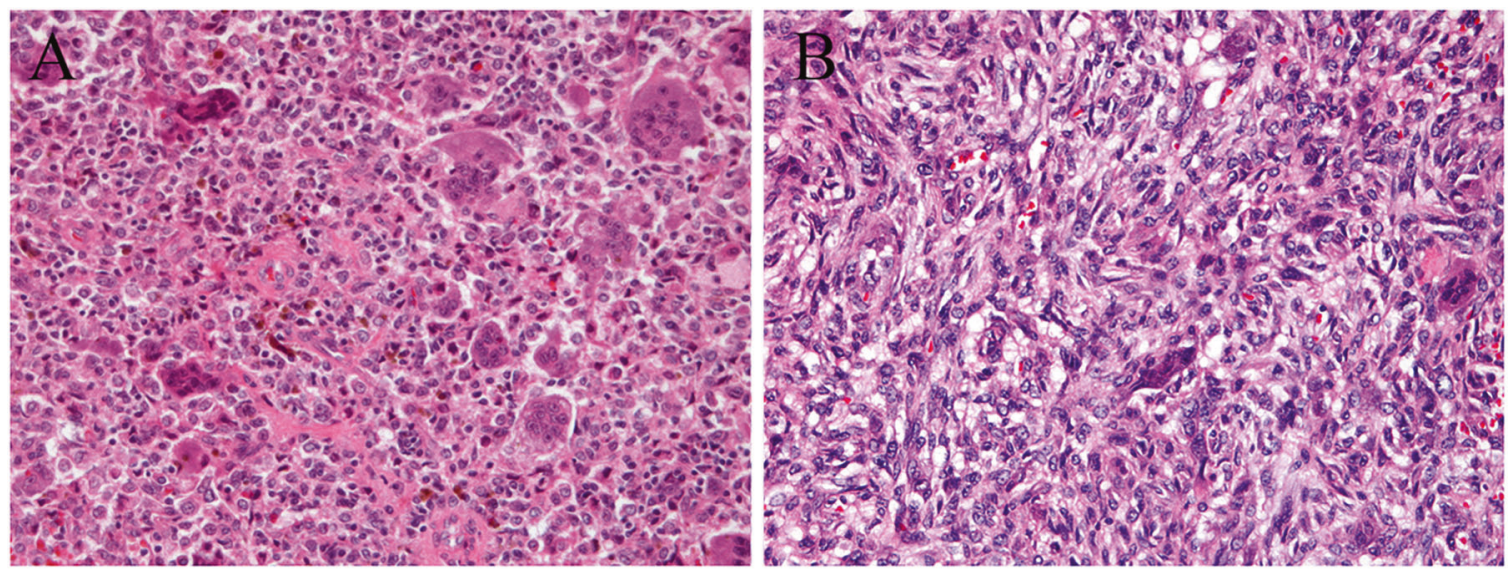

Fig. 1 Typical histology of ORUCUT. a Ovoid mononuclear cells intermixed with osteoclast-like giant cells. b Occasionally the mononuclear cells exhibited a more spindled morphology

Table 1 Details of antibodies used in immunohistochemistry

\begin{tabular}{llll}
\hline Antibody & Clone & Dilution & Vendor \\
\hline GATA3 & L50-823 & $1: 100$ & Biocare \\
Uroplakin II & BC21 & $1: 100$ & Biocare \\
Thrombomodulin & MS1009 & $1: 100$ & Dako \\
Cytokeratin AE1/3 & PCK-26 & Pre-diluted & Ventana
\end{tabular}

utilizes the more specific urothelial markers of GATA3, uroplakin II, and thrombomodulin.

\section{Materials and Methods}

Historical records, including consultation cases, at two tertiary care hospitals were searched. Seventeen of the twentyone cases $(81 \%)$ were from consultation cases from outside institutions received for review by one of the authors (JIE), with the remaining four cases primary to Johns Hopkins Hospital (JHH) and the Hospital of the University of Pennsylvania (HUP). Cases were accessioned between the years 1995 to 2015 . None of the 21 cases were previously reported in the literature. Representative hematoxylin and eosin stained and immunohistochemical slides from each case were reviewed by all the authors for agreement on the diagnosis. A single block from each case, which contained both mononuclear cells and osteoclast-like giant cells, was selected for immunohistochemistry from each case for this study. For all cases, the presence of in situ or invasive urothelial carcinoma was also noted.

Immunohistochemistry for all 21 cases was performed at JHH for GATA3, uroplakin II, thrombomodulin, and cytokeratin AE1/3 (Table 1). Immunohistochemistry was performed on 4- $\mu$ m-thick, deparaffinized sections using the standard streptavidin-biotin-immunoperoxidase complex method. Immunohistochemical results were reviewed by all the authors and were designated as either positive ( $\geq 5 \%$ of tumor cells staining) or negative $(<5 \%$ of tumor cells staining). Mononuclear-like and osteoclast-like giant cells were evaluated as separate populations. The percentage of positive tumor cells were quantified and binned as follows: focal $(<25 \%,+)$, moderate $(25-50 \%,++)$, and extensive $(>50 \%,+++)$.

The research protocol for this study was reviewed at JHH and HUP and approved by their respective Institutional Review Board.

\section{Results}

Patient demographics are presented in Table 2. The average age at diagnosis was 73 years (range 55-85) with a male to female ratio of 7:1. The advanced age and male bias is consistent with previous cases in the literature. In 15 (71\%) cases the tumor arose in the bladder, with the remaining 6 cases centered in the renal pelvis. All the tumors displayed the classic biphasic morphology of ORUCUT with osteoclast-like giant cells admixed with mononuclear cells (Fig. 1a). Mononuclear cells were often ovoid, but in a few instances appeared spindled (Fig. 1b) In 15 cases (71\%) there was association with either in situ or invasive urothelial carcinoma in addition to ORUCUT (Table 2). However, in some cases ORUCUT was adjacent to normal urothelium (Fig. 2).

Immunohistochemistry results are summarized in Table 2. The mononuclear cell population was positive for GATA3 in 95\% (20/21) of cases. Sixteen of the twenty (80\%) positive cases had moderate to extensive immunoreactivity in the mononuclear cell population (Fig. 3a). Only one case did not stain for GATA3. Thrombomodulin staining in the mononuclear cells was seen in 90\% (19/21) of cases. In contrast to GATA3 staining, thrombomodulin 
Table 2 Demographic information and immunohistochemical profiles of 21 cases of ORUCUT

\begin{tabular}{|c|c|c|c|c|c|c|c|c|}
\hline Case & $\begin{array}{l}\text { Age } \\
\text { (years) }\end{array}$ & Sex & GATA3 & Thrombomodulin & $\mathrm{AE} 1 / 3$ & Uroplakin & $\begin{array}{l}\text { Tumor } \\
\text { site }\end{array}$ & $\begin{array}{l}\text { Associated } \\
\text { lesions }\end{array}$ \\
\hline 1 & 82 & Male & +++ & + & Negative & Negative & $\begin{array}{l}\text { Renal } \\
\text { pelvis }\end{array}$ & INUC \\
\hline 2 & 77 & Male & +++ & + & Negative & Negative & Bladder & None \\
\hline 3 & 79 & Male & +++ & + & Negative & Negative & Bladder & None \\
\hline 4 & 73 & Male & +++ & + & Negative & Negative & $\begin{array}{l}\text { Renal } \\
\text { pelvis }\end{array}$ & INVPAP \\
\hline 5 & 55 & Male & ++ & + & Negative & Negative & Bladder & CIS \\
\hline 6 & 74 & Male & +++ & + & Negative & Negative & Bladder & INUC, CIS \\
\hline 7 & 68 & Male & + & Negative & Negative & Negative & Bladder & None \\
\hline 8 & 63 & Female & + & + & Negative & Negative & $\begin{array}{l}\text { Renal } \\
\text { pelvis }\end{array}$ & CIS \\
\hline 9 & 84 & Male & +++ & ++ & ++ & Negative & Bladder & INUC, CIS \\
\hline 10 & 76 & Male & +++ & + & Negative & Negative & Bladder & None \\
\hline 11 & 73 & Female & +++ & Negative & + & Negative & $\begin{array}{l}\text { Renal } \\
\text { pelvis }\end{array}$ & INUC \\
\hline 12 & 76 & Male & ++ & + & + & Negative & Bladder & INUC \\
\hline 13 & 66 & Male & ++ & + & Negative & Negative & Bladder & CIS \\
\hline 14 & 84 & Male & +++ & + & Negative & Negative & Bladder & None \\
\hline 15 & 72 & Male & Negative & + & Negative & Negative & Bladder & INUC, INSQ \\
\hline 16 & 73 & Male & ++ & + & Negative & Negative & Bladder & None \\
\hline 17 & 85 & Male & +++ & + & Negative & Negative & $\begin{array}{l}\text { Renal } \\
\text { pelvis }\end{array}$ & CIS \\
\hline 18 & 76 & Female & ++ & + & Negative & Negative & Bladder & LGPAP \\
\hline 19 & 63 & Male & +++ & + & Negative & Negative & Bladder & INVPAP \\
\hline 20 & 64 & Male & +++ & + & Negative & Negative & Bladder & HGPAP \\
\hline 21 & 73 & Female & + & + & Negative & Negative & Kidney & CIS \\
\hline
\end{tabular}

INUC invasive urothelial carcinoma, PAPUC papillary urothelial carcinoma, CIS carcinoma in situ, INVPAP invasive high-grade papillary urothelial carcinoma, INSQ invasive squamous cell carcinoma, LGPAP low-grade papillary urothelial carcinoma, HGPAP high-grade papillary urothelial carcinoma

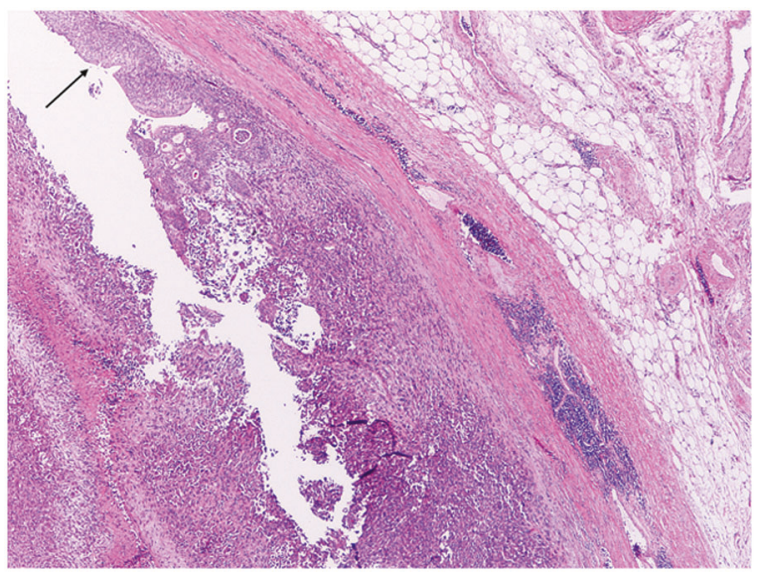

Fig. 2 ORUCUT arising adjacent to normal urothelium (arrow)

staining was focal in all cases, except for one that had moderate immunoreactivity (Fig. 3b). The case which was negative for GATA3 in the mononuclear cells was positive for thrombomodulin. Fourteen percent of cases (3/21) were positive for $\mathrm{AE} 1 / 3$ in the mononuclear cells. In all instances, this occurred in the tumor closest to in situ or invasive urothelial carcinoma. In none of the cases did the mononuclear population stain positive for uroplakin II. The osteoclast-like giant cells in all cases were negative for GATA3, thrombomodulin, uroplakin, and AE1/3.

\section{Discussion}

ORUCUT has been rarely described in the literature with approximately 20 case reports and small case series reported to date [15-33]. The largest prior case series by one of the current authors (JIE) on only six cases concluded that the mononuclear cells in ORUCUT were derived from urothelium based on three main findings: (1) the presence of at least focal epithelial staining (either AE1/3, Cam5.2, CK7 and or EMA) in 4/6 cases; (2) association of in situ or highgrade papillary urothelial carcinoma in all six cases; and (3) 


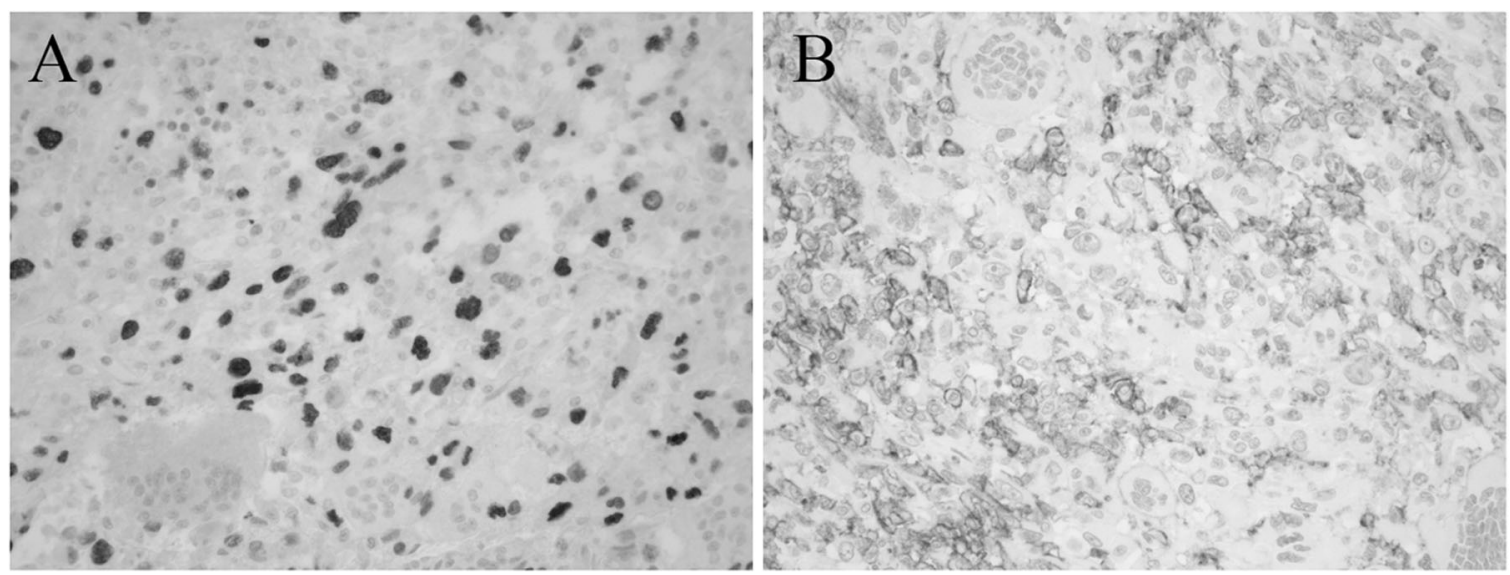

Fig. 3 Immunohistochemical staining in ORUCUT. a GATA3 showed extensive nuclear staining in most cases. b Thrombomodulin staining tended to be patchy compared to GATA3. Osteoclast-like giant cells were negative for both stains

matched p53 positivity in the conventional urothelial carcinoma and the ORUCUT mononuclear cells [10]. Overall in the literature, 22/28 (79\%) of cases of ORUCUT report associated conventional urothelial carcinoma. Further, the presence of mitotic activity and nuclear pleomorphism in the mononuclear cells highlighted their malignant behavior [10]. The lack of atypia and consistent immunohistochemical staining of the osteoclast-like giant cells supports their non-neoplastic, reactive, and histiocytic origin. The current study focused on further classifying the mononuclear cell population with more specific urothelial markers.

GATA3 belongs to a family of zinc-finger transcription factors. A systematic study of 2,500 epithelial and non-epithelial tumors for GATA3 reported $>90 \%$ staining in urothelial, ductal and lobular breast carcinomas, cutaneous basal cell carcinomas, and trophoblastic and endodermal sinus tumors. In addition, positivity was common in squamous cell tumors, skin adnexal tumors, mesothelioma, salivary gland, and pancreatic ductal carcinomas. Mesenchymal tumors displayed only sporadic positivity [34]. Thus, GATA3 is a sensitive and a specific maker for urothelial neoplasms when evaluating primary tumors in the bladder and renal pelvis [34, 35]. We observed positive staining in $95 \%$ of cases, which is strong evidence that the mononuclear cells are derived from urothelium.

Thrombomodulin is an integral membrane protein expressed on the surface of endothelial cells to serve as a cofactor for thrombin. Expression of thrombomodulin has also been noted in many tumors including urothelial, squamous, endothelial vascular tumors, and some adenocarcinomas. It is a fairly sensitive stain for urothelial carcinoma showing positivity in approximately $70-90 \%$ of cases $[36,37]$. In this series, thrombomodulin expression was seen in $90 \%$ of cases. In contrast to GATA3, the staining was patchy in all cases, except one. Positive staining for thrombomodulin further supports a urothelial origin for ORUCUT.
Uroplakin is a transmembrane protein found in normal and neoplastic urothelium. Various antibodies have been formulated against this target. Uroplakin II has the highest sensitivity in this group reported between 44 and $80 \%$, but overall has lower sensitivity for urothelial carcinoma than GATA3 and thrombomodulin [38, 39]. Uroplakin II was negative in all 21 cases. This is not surprising given the lower sensitivity of the antibody and the undifferentiated nature of ORUCUT. Staining with AE1/3 was predominantly negative, except for focal staining in three cases. Previously, multiple keratins were required to establish positive results in most cases [10].

Osteoclast-like giant cells were negative for GATA3, thrombomodulin, uroplakin II, and AE1/3, once again demonstrating their non-epithelial derivation. Like previous reports the osteoclast-like giant cells lacked atypia or mitosis, supporting their reactive and non-neoplastic nature.

Overall, the findings of this study more definitively support a urothelial origin for ORUCUT with positivity for two of three sensitive and specific markers of urothelial differentiation in the vast majority of cases. Although not all cases had concurrent conventional urothelial carcinoma, the majority showed this association further supporting that ORCUT is an undifferentiated variant of urothelial carcinoma.

\section{Compliance with Ethical Standards}

Conflict of interest The authors declare that they have no conflict of interest.

\section{References}

1. Fadare O, Mariappan MR, Ocal IT, et al. A malignant ovarian tumor with osteoclast-like giant cells. Am J Surg Pathol. $2003 ; 27: 854-60$. 
2. Eusebi V, Martin SA, Govoni E, et al. Giant cell tumor of major salivary glands: report of three cases, one occurring in association with a malignant mixed tumor. Am J Clin Pathol. 1984;81:666-75.

3. Wieneke JA, Gannon FH, Heffner DK, et al. Giant cell tumor of the larynx: a clinicopathologic series of eight cases and a review of the literature. Mod Pathol. 2001;14:1209-15.

4. Kuroda M, et al. Giant cell tumor of the lung: an autopsy case report with immunohistochemical observations. Pathol Int. 1994;44:158-63.

5. Munoz PA, Rao MS, Reddy JK. Osteoclastoma-like giant cell tumor of the liver. Cancer. 1980;46:771-9.

6. Silverberg SG, Degiorgi LS. Osteoclastoma-like giant cell tumor of the thyroid. Report of a case with prolonged survival following partial excision and radiotherapy. Cancer. 1973;31:621-5.

7. Maheswaran P, Addis B. Osteoclastoma-like giant cell tumour of the skin. Histopathology. 1990;16:604-7.

8. Dorney P. Osteoclastoma of the heart. Br Heart J. 1967;29:276-8.

9. Berendt RC, Shnitka TK, Wiens E, et al. The osteoclast-type giant cell tumor of the pancreas. Arch Pathol Lab Med. 1987;111:43-48.

10. Baydar D, Amin MB, Epstein JI. Osteoclast-rich undifferentiated carcinomas of the urinary tract. Mod Pathol. 2005;19:161-71.

11. Hutter RV, Worcester JN, Francis KC, et al. Benign and malignant giant cell tumors of bone. A clinicopathological analysis of the natural history of the disease. Cancer. 1962;15:653-90.

12. Tubbs WS, Brown L, Beabout JW, et al. Benign giant-cell tumor of bone with pulmonary metastases: clinical findings and radiologic appearance of metastases in 13 cases. Am J Roentgenol. 1992;158:331-4.

13. Balke M, et al. Giant cell tumor of bone: treatment and outcome of 214 cases. J Cancer Res Clin Oncol. 2008;134:969-78.

14. Reid MD, et al. Cytologic features and clinical implications of undifferentiated carcinoma with osteoclastic giant cells of the pancreas: an analysis of 15 cases. Cancer Cytopathol. 2017;125:563-75.

15. Holtz F, Fox JE, Abell MR. Carcinosarcoma of the urinary bladder. Cancer. 1972;29:294-304.

16. Lidgi S, Embon OM, Turani H, et al. Giant cell reparative granuloma of the bladder associated with transitional cell carcinoma. J Urol. 1989;142:120-2.

17. Behzatoğlu K, et al. Giant cell tumor-like lesion of the urinary bladder: a report of two cases and literature review; giant cell tumor or undifferentiated carcinoma? Diagn Pathol. 2009;4:48.

18. Kenney RM, Prat J, Tabernero M. Giant-cell tumor-like proliferation associated with a papillary transitional cell carcinoma of the renal pelvis. Am J Surg Pathol. 1984;8:139-44.

19. Kitazawa M, et al. Giant cell tumor of the bladder associated with transitional cell carcinoma. J Urol. 1985;133:472-5.

20. Kimura K, Ohnishi Y, Morishita H, et al. Giant cell tumor of the kidney. Virchows Arch. 1983;398:357-65.

21. Heller KN, Manyak MJ, Tabbara SO, et al. Malignant osteoclastlike giant cell tumor of the kidney. Urology. 1998;51:495-8.
22. Borg-Grech A, Morris J, Eyden BP. Malignant osteoclastoma-like giant cell tumour of the renal pelvis. Histopathology. 1987;11:415-25.

23. Wu PJ, Su CK, Li JR, et al. Osteoclast-like giant cell carcinoma of the urinary bladder. J Chin Med Assoc. 2009;72:495-7.

24. Akhtar M, Aslam M, Lindstedt E, et al. Osteoclast-like giant cell tumor of renal pelvis. J Urol Pathol. 1999;11:181-94.

25. Amir G, Rosenmann E. Osteoclast-like giant cell tumour of the urinary bladder. Histopathology. 1990;17:413-8.

26. Molinie V, Pouchot J, Vinceneux P, et al. Osteoclastoma-like giant cell tumor of the renal pelvis associated with papillary transitional cell carcinoma. Arch Pathol Lab Med. 1997;121:162.

27. Kawano $\mathrm{H}$, et al. Osteoclast-rich undifferentiated carcinoma of the urinary bladder: an immunohistochemical study. Pathol Res Pract. 2011;207:722-7.

28. Castelino-Prabhu S, Ali SZ. Osteoclast-rich undifferentiated carcinoma of the urinary tract: cytologic findings and literature review. Diagn Cytopathol. 2010;38:364-7.

29. Kanthan R, Torkian B. Primary de novo malignant giant cell tumor of kidney: a case report. BMC Urol. 2004;4:7.

30. O'connor RC, et al. Recurrent giant cell carcinoma of the bladder. J Urol. 2002;167:1784.

31. Zanella M, Falconieri G. Sarcomatoid urothelial carcinoma of the renal pelvis: report of two cases with extensive osteoclast-like giant cell components. J Urol Pathol. 2000;12:13-28.

32. Zukerberg L, Armin A, Pisharodi L, et al. Transitional cell carcinoma of the urinary bladder with osteoclast-type giant cells: a report of two cases and review of the literature. Histopathology. 1990;17:407-11.

33. McCash SI, Unger P, Dillon R, et al. Undifferentiated carcinoma of the renal pelvis with osteoclast-like giant cells: a report of two cases. Apmis. 2010;118:407-12.

34. Miettinen M, et al. GATA 3-a multispecific but potentially useful marker in surgical pathology-a systematic analysis of 2500 epithelial and non-epithelial tumors. Am J Surg Pathol. 2014;38:13-22.

35. Higgins JPT, et al. Placental S100 (S100P) and GATA3: markers for transitional epithelium and urothelial carcinoma discovered by complementary DNA microarray. Am J Surg Pathol. 2007;31:673-80.

36. Parker DC, et al. Potential utility of uroplakin III, thrombomodulin, high molecular weight cytokeratin, and cytokeratin 20 in noninvasive, invasive, and metastatic urothelial (transitional cell) carcinomas. Am J Surg Pathol. 2003;27:1-10.

37. Ordóñez NG. Thrombomodulin expression in transitional cell carcinoma. Am J Clin Pathol. 1998;110:385-90.

38. Hoang LL, et al. A newly developed uroplakin II antibody with increased sensitivity in urothelial carcinoma of the bladder. Arch Pathol Lab Med. 2014;138:943-9.

39. $\mathrm{Li} \mathrm{W}$, et al. Uroplakin II is a more sensitive immunohistochemical marker than uroplakin III in urothelial carcinoma and its variants. Am J Clin Pathol. 2014;142:864-71. 